\title{
Efektivitas SIPKD, Gaya Kepemimpinan, dan Lingkungan Kerja Pada Kinerja Karyawan Dinas Pariwisata Provinsi Bali
}

\author{
I Gusti Agung Brawijaya1 \\ Fakultas Ekonomi dan Bisnis \\ Universitas Udayana, Indonesia \\ Email: brawijayaagung@gmail.com
}

\author{
Made Yenni Latrini2 \\ Fakultas Ekonomi dan Bisnis \\ Universitas Udayana, Indonesia
}

\begin{abstract}
ABSTRAK
Kinerja Karyawan memegang peran penting dalam keberhasilan suatu organisasi. Suatu organisasi mengharapkan karyawan dapat menyelesaikan tugas secara tepat waktu, akurat, dan reliable. Salah satu wujud pemerintah dalam meningkatkan kinerja karyawannya yaitu dengan penerapan SIPKD. Penelitian ini dilakukan pada Dinas Pariwisata Provinsi Bali. Tujuan penelitian adalah untuk mengetahui seberapa besar efektivitas SIPKD, gaya kepemimpinan, dan lingkungan kerja pada kinerja karyawan. Metode pemilihan sampel dalam penelitian ini menggunakan teknik sampel jenuh (sensus). Jumlah sampel dalam penelitian ini adalah sebanyak 40 orang. Hasil penelitian ini menunjukan bahwa efektivitas SIPKD tidak berpengaruh signifikan pada kinerja karyawan. Sedangkan gaya kepemimpinan dan lingkungan kerja berpengaruh positf dan signifikan pada kinerja karyawan Dinas Pariwisata Provinsi Bali.
\end{abstract}

Kata Kunci: Efektivitas SIPKD; Gaya Kepemimpinan; Lingkungan Kerja.

\section{Effectiveness of SIPKD, Leadership Style, and Work Environment on Employee Performance of the Bali Provincial Tourism Office}

\begin{abstract}
Employee Performance plays an important role in the success of an organization. An organization expects employees to complete tasks in a timely, accurate, and reliable manner. One form of government in improving the performance of its employees is the application of SIPKD. This research was conducted at the Bali Provincial Tourism Office. The purpose of this research is to find out how much effectiveness SIPKD, leadership style, and work environment have on employee performance. The sample selection method in this study uses the saturated sample (census) technique. The number of samples in this study were 40 people. The results of this study indicate that the effectiveness of SIPKD has no significant effect on employee performance. While the leadership style and work environment have a positive and significant influence on the performance of the employees of the Bali Provincial Tourism Office.
\end{abstract}

Keywords: Effectiveness of SIPKD; Leadership Style; Work Environment.

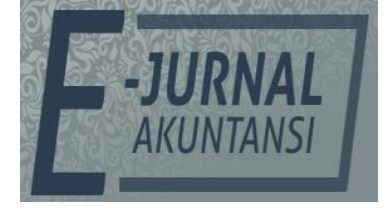

E-JA

e-Jurnal Akuntansi e-ISSN 2302-8556

Vol. 30 No. 2

Denpasar, Februari 2020

Hal. 517-527

Artikel Masuk: 21 November 2019

Tanggal Diterima: 22 Januari 2020 


\section{PENDAHULUAN}

Penerapan teknologi Informasi (TI) yang dikembangkan dalam pemerintahan atau yang disebut dengan e-government membuat masyarakat semakin mudah dalam mengakses kebijakan pemerintah sehingga program yang telah dirancang pemerintah dapat berjalan dengan lancar dan efisien. Penerapan TI di sektor publik telah memberi manfaat bagi organisasi pemerintah atau masyarakat, namun dalam penerapan TI di sektor publik dimungkinkan terjadinya kegagalan. Berdasarkan penelitian di New Zealand, yang dilakukan oleh Goldfinch, (2007), menunjukkan bahwa 38\% proyek sistem di pemerintah berhasil, 59\% bermasalah, dan 3\% gagal atau dibatalkan. Hal ini menunjukkan bahwa penerapan sistem di organisasi sektor publik perlu lebih hati hati karena adanya benturan kepentingan antara birokrasi, manajerial, dan programmer.

Selain efektivitas penerapan sistem informasi khususnya sistem informasi akuntansi untuk meningkatkan kinerja karyawan dalam suatu perusahaan, perusahaan juga memerlukan seorang pemimpin untuk memotivasi dan mengarahkan bawahannya. Pemimpin bisa mempengaruhi kinerja, kepuasan kerja, keamanan, dan semangat kerja karyawan dalam suatu organisasi. Peran pemimpin dalam mempengaruhi kinerja karyawan dapat dilihat dari gaya kepemimpinan. Gaya kepemimpinan adalah suatu cara yang dilakukan oleh pemimpin dalam mempengaruhi perilaku orang lain. James, et al., (1996) mengemukakan bahwa gaya kepemimpinan adalah berbagai pola tingkah laku yang disukai oleh pemimpin dalam proses mengarahkan dan mempengaruhi para pekerja. Sedangkan pengertian kepemimpinan menurut Dubrin, (2005) mengemukakan bahwa kepemimpinan adalah upaya untuk mempengaruhi banyak orang melalui komunikasi untuk mencapai tujuan, cara mempengaruhi orang dengan petunjuk atau perintah, tindakan yang menyebabkan orang lain bertindak atau merespon dengan tindakan positif. Kepemimpinan yang dibutuhkan ialah kepemimpinan yang bisa memberdayakan karyawannya serta yang bisa meningkatkan rasa percaya diri terhadap kerja karyawan.

Kepemimpinan dianggap suatu hal yang sangat penting karena dua hal, yang pertama karena banyak sekali kenyataan bahwa jika perusahaan mengalami pergantian pemimpin, maka hal itu akan mempengaruhi kinerja suatu unit, instansi, atau organisasi. Kedua adalah adapun suatu faktor internal yang mempengaruhi kesuksesan organisasi adalah kepemimpinan, dimana hal ini mencakup semua proses kepemimpinan, kompetensi, dan tindakan pemimpin pada suatu organisasi. Dengan kata lain, kepemimpinan merupakan sebuah faktor yang sangat penting untuk mempengaruhi dan memberikan arahan kepada karyawan. Dalam proses mempengaruhi, mengarahkan, ataupun mengkoordinasi karyawannya, seorang pemimpin harus memperhatikan gaya kepemimpinannya, agar nantinya tujuan perusahaan dapat tercapai dengan baik.

Keberhasilan seorang pemimpin untuk mempengaruhi kinerja seorang karyawan dalam bekerja tidak terlepas dari faktor lingkungan kerja. Lingkungan kerja akan berpengaruh positif terhadap kinerja karyawan jika lingkungan kerja di suatu organisasi tersebut kondusif. Menurut Nitisemito, (1996) lingkungan kerja adalah segala sesuatu yang ada disekitar pekerja dan dapat mempengaruhi mereka dalam menjalankan tugas-tugas yang dibebankan. Menurut Sedarmayanti, (2009) mendefinisikan lingkungan kerja merupakan keseluruhan 
alat perkakas ataupun bahan yang dihadapi, lingkungan sekitarnya dimana seseorang bekerja, metode kerjanya, serta pengukuran kerjanya baik sebagai perseorangan maupun sebagai kelompok .Selain itu menurut Saydam, (2000) yang mendefinisikan lingkungan kerja sebagai keseluruhan sarana atau prasarana kerja yang ada disekitar karyawan yang sedang melaksanakan pekerjaan yang dapat mempengaruhi kinerja karyawan itu sendiri.

Berdasarkan pendapat diatas dapat disimpulkan bahwa lingkungan kerja merupakan suatu kondisi lingkungan dimana para karyawan bekerja dalam suatu perusahaan, yang kondisi tersebut mempengaruhi kondisi fisik dan psikologi seseorang baik secara langsung maupun tidak langsung.

Lingkungan kerja dapat dikatakan baik atau kondusif apabila karyawan dapat bekerja secara optimal, tenang dan produktivitasnya tinggi sehingga akan membantu perusahaan dalam mencapai target yang telah ditentukan. Semakin baik atau kondusif lingkungan kerja suatu perusahaan, akan semakin membantu karyawan untuk meningkatkan produktivitasnya.

Dinas Pariwisata Provinsi Bali sebagai regulator dan pengorganisasian aturan-aturan yang mendukung pariwisata di Bali yang sangat berperan penting untuk kemajuan kepariwisataan, dimana Dinas Pariwisata Provinsi Bali menggali dan mengembangkan potensi-potensi yang ada di Bali sehingga nantinya menjadi daya tarik wisata yang menarik dalam meningkatkan perekonomian di Bali. Dengan banyaknya jumlah wisatawan yang berkunjung ke Bali menuntut pengguna sistem informasi akuntansi khususnya di Dinas Pariwisata Provinsi Bali agar memiliki kemampuan yang baik dalam mengelola sistem sehingga informasi yang dihasilkan dari proses pengelolaan data dapat lebih akurat.

Dalam rangka mewujudkan pelayanan prima kepada masyarakat di bidang keuangan atau akuntansi serta membantu kinerja karyawan dalam pengolahan data keuangan, pemerintah telah membangun teknologi di bidang keuangan atau akuntansi yang kaitannya dengan pengelolaan keuangan daerah yaitu Sistem Informasi Pengelolaan Keuangan Daerah atau SIPKD. SIPKD merupakan aplikasi yang dibangun oleh Ditjen Keuangan Daerah Kementerian Dalam Negeri Republik Indonesia dalam rangka percepatan transfer data dan efisiensi dalam penghimpunan data keuangan daerah. Sistem informasi pengelolaan keuangan daerah merupakan aplikasi terpadu yang dipergunakan sebagai alat bantu pemerintah daerah yang digunakan meningkatkan efektifitas implementasi dari berbagai regulasi bidang pengelolaan keuangan daerah yang berdasarkan pada asas efisiensi, ekonomis, efektif, transparan, akuntabel dan auditable (www.djkd.kemendagri.go.id, 2018). SIPKD tersebut nantinya memuat informasi tentang proses penyusunan Anggaran Pendapatan dan Belanja Daerah.

Dinas Pariwisata Provinsi Bali merupakan salah satu instansi pemerintah yang telah menerapkan Sistem Informasi Keuangan Daerah dalam membantu kinerja karyawannya. Berdasarkan isu penelitian sebelumnya yang dilakukan oleh Yustikarana \& Wirakusuma, (2019) dalam penerapan sistem tersebut terdapat beberapa kendala diantaranya para pengguna masih kurang yang terlibat dalam menggunakan sistem tersebut karena perubahan cara kerja dari sistem manual menjadi sistem yang berbasis pada teknologi informasi membuat para pengguna tidak mudah melakukan koreksi jika terjadi kesalahan. Tentunya 
hal ini nantinya berdampak pada keterlambatan dalam penyampaian laporan keuangan yang mempengaruhi dalam pengambilan keputusan dan kinerja karyawan.

Penelitian ini merupakan pengembangan isu dari penelitian yang telah dilakukan oleh Yustikarana \& Wirakusuma, (2019) yang berjudul Pengaruh Kemampuan dan Keterlibatan Pengguna Terhadap Kinerja Sistem Informasi Pengelolaan Keuangan Daerah, yang dilakukan di Dinas Pariwisata Provinsi Bali. Perbedaan penelitian ini dengan penelitian sebelumnya terletak pada variabel dependen yang dimana penelitian ini menggunakan kinerja karyawan sebagai variabel dependennya, sedangkan penelitian sebelumnya menggunakan kinerja Sistem Informasi Pengelolaan Keuangan Daerah sebagai variabel dependen yang hasilnya Kemampuan dan Keterlibatan Pengguna berpengaruh positif terhadap Kinerja Sistem Informasi Pengelolaan Keuangan Daerah.

Putra \& Putra, (2016) menggunakan model TPC (Technology to Performance Chain) yang dikembangkan oleh Goodhue yang mencoba keberhasilan "teknologi sistem informasi“ yang diterapkan dalam organisasi atau perusahaan dengan menggunakan evaluasi pemakai. Efektivitas berkaitan dengan relevansi suatu informasi dalam mendukung suatu proses bisnis, termasuk didalamnya harus disajikan dalam waktu yang tepat, akurat, konsisten, dapat digunakan, dan lengkap. Apabila teknologi informasi yang tersedia cocok dengan tugas yang harus diselesaikan dan kemampuan individu pemakai, maka akan memanfaatkan teknologi tersebut dalam menjalankan tugasnya. Hal ini akan berpengaruh pada pencapaian kinerja individual yang diharapkan, semakin baik teknologi yang diterapkan maka pencapaian kinerja individual akan semakin tinggi. Efektivitas sistem informasi akuntansi terkait dengan gambaran sejauh mana target dapat dicapai dengan memanfaatkan sumber daya yang diatur untuk mengumpulkan, memproses, dan menyimpan data elektronik, kemudian mengubahnya menjadi informasi yang dibutuhkan. SIPKD di dalam suatu instansi pemerintah tidak hanya tidak hanya bertujuan untuk meningkatkan efisiensi, tetapi juga untuk mendukung terjadinya proses kinerja yang lebih efektif.

Nurlaela, et al., (2014) menyatakan bahwa semakin baik sistem informasi akuntansi di suatu organisasi, maka akan semakin meningkat pula kinerja karyawan dalam suatu organisasi tersebut. Sedangkan Menurut Awosejo et al., (2013) Menyatakan bahwa adanya sistem informasi akuntansi dalam sebuah organisasi dapat meningkatkan kinerja individu. Berdasarkan uraian diatas, maka rumusan hipotesis yang digunakan yaitu:

$\mathrm{H}_{1}$ : Efektivitas penerapan Sistem Informasi Pengelolaan Keuangan Daerah berpengaruh positif terhadap kinerja karyawan.

Dalam Teori Perilaku diungkapkan bahwa bagaimana seorang pemimin mempengaruhi orang lain dan hal ini dipengaruhi oleh gaya kepemimpinan. Gaya Kepemimpinan pada dasarnya adalah suatu cara oleh pemimpin untuk menguasai seseorang dalam mengerjakan sesuatu. Gaya Kepemimpinan pada dasarnya menekankan untuk menghargai tujuan individu akan memiliki keyakinan bahwa kinerja aktual akan melampaui harapan kinerja mereka. Jika Kepemimpinan tersebut terjadi pada suatu organisasi formal tertentu, dimana para manajer perlu mengembangkan karyawan, membangun iklim motivasi, 
menjalankan fungsi-fungsi manajerial dalam rangka menghasilkan kinerja yang tinggi dan meningkatkan kinerja perusahaan, maka manajer perlu untuk menyesuaikan gaya kepemimpinan (Siagian, 2003).

Penelitian yang dilakukan oleh Reza, (2010), dan Prista, (2016) menyatakan bahwa gaya kepemimpinan berpengaruh positif terhadap kinerja karyawan. Semakin baiknya seorang pemimpin dalam mengatur/mempengaruhi bawahannya, maka bawahannya akan semakin termotivasi dan bersemangat untuk bekerja, sehingga kualitas kerja (kinerja) bawahannya akan semakin baik. Dari hasil penelitian terdahulu tersebut dapat disimpulkan bahwa terdapat hubungan yang positif antara gaya kepemimpinan dengan kinerja karyawan. Berdasarkan uraian diatas, maka rumusan hipotesis yang digunakan yaitu:

$\mathrm{H}_{2}$ : Gaya Kepemimpinan berpengaruh positif terhadap kinerja karyawan

Pengaruh Lingkungan kerja terhadap kinerja pegawai diungkapkan oleh Winardi, (2007) lingkungan kerja merupakan suatu alat ukur yang akan berpengaruh terhadap kinerja karyawan jika lingkungan kerja yang terdapat di suatu instansi itu baik. Lingkungan kerja yang menyenangkan bagi pegawai melalui peningkatan hubungan yang harmonis dengan atasan, rekan kerja, maupun bawahan, serta didukung oleh sarana dan prasarana yang memadai yang ada di tempat kerja akan membawa dampak yang positif bagi karyawan, sehingga kinerja karyawan dapat meningkat.

Berdasarkan Penelitian yang dilakukan oleh Yulianingtyas, (2008), menyatakan bahwa pengaruh kepuasan karyawan pada gaya kepemimpinan dan lingkungan kerja berpengaruh positif terhadap kinerja karyawan. Berdasarkan uraian tersebut, maka rumusan hipotesis yang digunakan yaitu:

$\mathrm{H}_{3}$ : Lingkungan Kerja berpengaruh positif terhadap kinerja karyawan.

\section{METODE PENELITIAN}

Penelitian ini dilakukan di Dinas Pariwisata yang berada di Kota Denpasar. Pemilihan Dinas Pariwisata Provinsi Bali sebagai lokasi penelitian karena pemakaian sistem SIPKD di Dinas Pariwisata Provinsi Bali masih terbilang baru. Hal tersebut berdampak pada kinerja karyawan yang harus beradaptasi dengan sistem baru yang dianutnya.

Populasi dalam penelitian ini adalah seluruh pengguna SIPKD yang bekerja di Dinas Pariwisata Provinsi Bali. Teknik penetapan sampel yang digunakan adalah teknik sampel jenuh (sensus). sampel jenuh adalah teknik penentuan sampel bila semua anggota populasi digunakan sebagai sampel. Hal ini terjadi pada DISPARDA yang memiliki jumlah populasi yang kecil yaitu seluruh pegawai negeri sipil yang terlibat dalam sistem informasi pengelolaan keuangan daerah di Dinas Pariwisata Provinsi Bali, jadi jumlah sampel dan jumlah populasi sebanyak 40 orang.

Teknik analisis data yang digunakan dalam penelitian ini adalah analisis regresi linear berganda. Analisis regresi berganda adalah pengujian yang dilakukam untuk mengetahui ada tidaknya pengaruh efektivitas penerpaan SIPKD (X1), gaya kepemimpinan (X2), dan lingkungan kerja (X3) terhadap kinerja karyawan (Y). Model regresi linear berganda ditunjukkan dalam persamaan sebagai berikut: 
$Y=\alpha+\beta 1 X 1+\beta 2 X 2+\beta 3 X 3+e$

Keterangan:

$\mathrm{Y}=$ Kinerja sistem informasi pengelolaan keuangan daerah

a $\quad=$ Konstan

$\mathrm{X} 1=$ Penerapan SIPKD

$\mathrm{X} 2=$ Gaya Kepemimpinan

$\mathrm{X} 3=$ Lingkungan Kerja

$\beta 1=$ Koefisien regresi efektivitas penerapan SIPKD

$\beta 2=$ Koefisien regresi gaya kepemimpinan

$\beta 3=$ Koefisien regresi lingkungan kerja

e $\quad=$ Komponen error

\section{HASIL DAN PEMBAHASAN}

Analisis regresi linier berganda ini digunakan untuk menganalisis Efektivitas Penerapan SIPKD $\left(X_{1}\right)$, Gaya Kepemimpinan $\left(X_{2}\right)$, dan Lingkungan Kerja $\left(X_{3}\right)$ terhadap Kinerja Karyawan (Y). Tabel 1 menunjukkan hasil analisis regresi linier berganda sebagai berikut:

Tabel 1. Hasil Uji Regresi Linear Berganda

\begin{tabular}{llllll}
\hline Model & \multicolumn{2}{l}{$\begin{array}{l}\text { Unstandardized } \\
\text { Coefficients }\end{array}$} & \multicolumn{2}{l}{$\begin{array}{l}\text { Standardized } \\
\text { Coefficients }\end{array}$} \\
& $\mathrm{B}$ & Std. Error & Beta & $\mathrm{t}$ & Sig. \\
\hline Constant & 21,754 & 4,177 & & 5,208 & 0,00 \\
Efektivitas SIPKD & .130 & .079 & .244 & 1.650 & .108 \\
Gaya Kepemimpinan & -.700 & .245 & -.506 & -2.854 & .007 \\
Lingkungan Kerja & .430 & .179 & .434 & 2.409 & .021 \\
& & & & & \\
Adjusted R Square & 0,194 & & & & \\
F & 4,128 & & & & \\
Sig. & $0,013^{\mathrm{b}}$ & & & & \\
\hline
\end{tabular}

Sumber: Data Penelitian, 2019

Berdasarkan Tabel 1. dapat disusun persamaan regresi sebagai berikut :

$$
Y=21,754+0,130 X_{1}+(-) 0,700 X_{2}+0,430 X_{3}
$$

Nilai konstanta sebesar 21,754 yaitu jika nilai efektivitas penerapan SIPKD, Gaya Kepemimpinan, dan Lingkungan Kerja sama dengan nol, maka nilai Kinerja Karyawan adalah sebesar 21,754. Koefisien regresi $\left(b_{1}\right)$ pada Efektivitas Penerapan SIPKD $\left(\mathrm{X}_{1}\right)$ bernilai 0,130 mempunyai hubungan positif terhadap kinerja karyawan. Artinya, bila nilai Efektivitas Penerapan SIPKD $\left(X_{1}\right)$ bertambah, maka kinerja karyawan $(Y)$ akan mengalami peningkatan sebesar 0,550 dengan asumsi variabel bebas lainnya konstan. Koefisien regresi $\left(b_{2}\right)$ pada Gaya Kepemimpinan $\left(\mathrm{X}_{2}\right)$ bernilai -0,700 mempunyai hubungan negatif terhadap kinerja karyawan. Artinya, bila nilai gaya kepemimpinan $\left(X_{2}\right)$ bertambah, maka kinerja karyawan $(Y)$ akan mengalami penurunan sebesar 0,700 dengan asumsi variabel bebas lainnya konstan. Koefisien regresi $\left(b_{2}\right)$ pada lingkungan kerja $\left(X_{3}\right)$ bernilai 0,430 mempunyai hubungan positif terhadap kinerja karyawan. Artinya, bila nilai lingkungan kerja $\left(\mathrm{X}_{3}\right)$ bertambah, maka kinerja karyawan $(\mathrm{Y})$ akan mengalami penurunan sebesar 0,430 dengan asumsi variabel bebas lainnya konstan. 
Koefisien determinasi (Adjusted R2) digunakan untuk mengetahui dan mengukur kemampuan model dalam menerangkan variasi variabel independen. Peneliti menggunakan nilai adjusted R2 pada saat mengevaluasi yang mana model regresi terbaik, karena tidak seperti R2, nilai adjusted R2 dapat naik atau turun apabila satu variabel independen ditambahkan ke dalam model. Hasil uji koefisien determinasi dalam penelitian ini dapat dilihat pada Tabel 1.

Hasil uji pada Tabel 1. menunjukan besarnya adjusted $\mathrm{R}^{2}$ (koefisien determinasi yang telah disesuaikan) adalah sebesar 0,194 mempunyai arti bahwa sebesar 19,4\% variasi kinerja karyawan pada Dinas Pariwisata Provinsi Bali dipengaruhi oleh variasi penerapan SIPKD, gaya kepemimpinan, dan lingkungan kerja, sedangkan sisanya sebesar 80,6 \% djelaskan oleh faktor lain yang tidak dimasukkan ke dalam model.

Uji kelayakan model atau yang lebih populer disebut sebagai uji $\mathrm{F}$ merupakan tahapan awal mengidentifikasi model regresi yang diestimasi layak atau tidak. Hasil uji regresi dinyatakan layak apabila memiliki nilai signifikansi uji $\mathrm{F}$ kurang dari 0,05. Hasil uji $\mathrm{F}$ dalam penelitian ini dapat dilihat pada Tabel 4.9 Hasil uji $\mathrm{F}$ (F test) pada Tabel 1 menunjukkan bahwa nilai $\mathrm{F}$ hitung sebesar 4,128 dengan nilai signifikansi $P$ value 0,013 yang lebih kecil dari $\alpha<0,05$.

Hal ini menunjukan model yang digunakan pada penelitian ini adalah layak. Hasil ini memberikan makna bahwa ketiga variabel independen yaitu efektivitas penerapan SIPKD, gaya kepemimpinan, dan lingkungan kerja tepat memprediksi atau menjelaskan fenomena kinerja karyawan Dinas Pariwisata Provinsi Bali. Hal ini berarti model dapat digunakan untuk analisa lebih lanjut atau dengan kata lain model dapat digunakan untuk memproyeksikan karena hasil goodness of fitnya baik dengan nilai $\mathrm{F}$ hitung sebesar 4,128 dengan nilai signifikansi P value 0,013.

Pada tabel 1. dapat dilihat bahwa hasil analisis efektivitas penerapan SIPKD diperoleh nilai Signifikansi sebesar 0,108 dengan nilai koefisien beta 0,244. Nilai Signifikansi 0,108 $>0,05$ mengindikasikan bahwa $\mathrm{H}_{0}$ diterima dan $\mathrm{H}_{1}$ ditolak. Hasil ini mempunyai arti bahwa efektivitas penerapan SIPKD tidak berpengaruh signifikan pada kinerja karyawan Dinas Pariwisata Provinsi Bali.

Pada tabel 1. dapat dilihat bahwa hasil analisis pengaruh gaya kepemimpinan terhadap kinerja karyawan diperoleh nilai Signifikansi sebesar 0,007 dengan nilai koefisien beta -0,506. Nilai Signifikansi 0,007 0,05 mengindikasikan bahwa $\mathrm{H}_{0}$ ditolak dan $\mathrm{H}_{2}$ diterima. Hasil ini mempunyai arti bahwa gaya kepemimpinan berpengaruh positif dan signifikan terhadap kinerja karyawan Dinas Pariwisata Provinsi Bali.

Pada tabel 1 dapat dilihat bahwa hasil analisis pengaruh ;ingkungan kerja terhadap kinerja karyawan diperoleh nilai Signifikansi sebesar 0,021 dengan nilai koefisien beta 0,434. Nilai Signifikansi 0,021 <0,05 mengindikasikan bahwa $\mathrm{H}_{0}$ ditolak dan $\mathrm{H}_{3}$ diterima. Hasil ini mempunyai arti bahwa lingkungan kerja berpengaruh positif dan signifikan terhadap kinerja karyawan Dinas Pariwisata Provinsi Bali.

Pada tabel 1. dapat dilihat bahwa hasil analisis pengaruh efektivitas penerapan SIPKD pada kinerja karyawan diperoleh nilai signifikansi sebesar 0,108 dengan nilai koefisien beta 0,244. Nilai signifikansi 0,108 > 0,05 mengindikasikan bahwa $\mathrm{H}_{0}$ diterima dan $\mathrm{H}_{1}$ ditolak. Hasil ini menunjukan 
bahwa efektivitas penerapan SIPKD terhadap kinerja karyawan tidak berpengaruh signifikan Dalam kondisi ini maka karyawan tidak menikmati keuntungan dari penerapan SIPKD. Hal ini bisa saja disebabkan oleh penerapan SIPKD yang baru saja dimulai pada tahun 2018, sehingga pengguna masih perlu melakukan adaptasi agar nantinya penerapan SIPKD bisa berjalan secara efektif dan optimal pada kinerja karyawan Dinas Pariwisata Provinsi Bali

Berdasarkan hasil statistik deskriptif, pernyataan hasil kuisoner dengan nilai rata-rata jawaban terendah untuk variabel efektivitas penerapan SIPKD adalah item kedua, keempat, dan kelima yaitu "Penerapan Sistem Informasi Pengelolaan Keuangan Daerah dapat dipahami dan diterapkan secara mudah (2), Melalui penerapan sistem tersebut, informasi yang dihasilkan terjamin keamanannya (4), Sistem Informasi Pengelolaan Keuangan Daerah di tempat saya bekerja bersifat user-friendly" hal ini menunjukan bahwa efektivitas penerapan SIPKD di Dinas Pariwisata Provinsi Bali belum dapat memberikan kontribusi secara signifikan untuk pencapaian tujuan dan misi organisasi. Hasil penelitian ini mendukung penelitian Soudani, (2012) yaitu hasil tidak mendukung adanaya hubungan positif antara sistem informasi akuntansi terhadap kinerja karyawan. Dan penelitian yang dilakukan oleh Christianto, et al., (2007) menunjukan bahwa implementasi sistem informasi berdampak negatif terhadap produktivitas tenaga kerja.

Pada table 1 dapat dilihat bahwa hasil analisis pengaruh gaya kepemimpinan pada kinerja karyawan diperoleh nilai Signifikansi sebesar 0,007 dengan nilai koefisien beta -0,506. Nilai Signifikansi 0,007 $<0,05$ mengindikasikan bahwa $\mathrm{H}_{0}$ ditolak dan $\mathrm{H}_{2}$ diterima. Hasil ini menunjukan bahwa gaya kepemimpinan berpengaruh positif dan signifikan pada kinerja karyawan Dinas Pariwisata Provinsi Bali yang artinya semakin baik seorang pemimpin dalam mengatur/mempengaruhi bawahannya, maka bawahannya akan semakin termotivasi untuk bekerja yang membantu mendorong keberhasilan tujuan organisasi di Dinas Pariwisata Provinsi Bali.

Berdasarkan hasil statistik deskriptif, pernyataan hasil kuisoner dengan nilai rata-rata jawaban tertinggi untuk variabel gaya kepemimpinan adalah item keempat yaitu "Pemimpin saya selalu menjelaskan keputusan yang akan ditetapkannya" hal ini menunjukan bahwa karyawan merasa sangat puas dengan kepemimpinan yang telah diterapkan, sehingga berdampak pada kinerja karyawan yang meningkat untuk pencapaian tujuan organisasi. Hasil penelitian ini mendukung penelitian yang dilakukan oleh Reza, (2010), dan Prista, (2016) yang menyatakan bahwa gaya kepemimpinan berpengaruh positif terhadap kinerja karyawan

Pada tabel 1 dapat dilihat bahwa hasil analisis pengaruh lingkungan kerja pada kinerja karyawan diperoleh nilai Signifikansi sebesar 0,021 dengan nilai koefisien beta 0,434. Nilai Signifikansi 0,021 < 0,05 mengindikasikan bahwa $\mathrm{H}_{0}$ ditolak dan $\mathrm{H}_{3}$ diterima. Hasil ini menunjukan bahwa lingkungan kerja berpengaruh positif dan signifikan pada kinerja karyawan Dinas Pariwisata Provinsi Bali yang artinya semakin kondusif lingkungan kerja, maka kinerja karyawan akan semakin meningkat.

Berdasarkan hasil statistik deskriptif, pernyataan hasil kuisoner dengan nilai rata-rata jawaban tertinggi untuk variabel lingkungan kerja adalah item 
ketiga, keempat, dan keenam yaitu "lingkungan kerja karyawan tenang dan bebas dari suara bising (3), Warna dinding pada ruangan kerja saya sangat mendukung keadaan pikiran saya untuk bekerja (4), Adanya petugas keamanan di lingkungan kantor membuat saya bekerja dengan sangat nyaman (6) " hal ini menunjukan bahwa karyawan dapat bekerja dengan optimal, tenang, dan mempunyai produktivitas yang tinggi. Hasil penelitian ini mendukung penelitian yang dilakukan Kusmayadi, (2014) yang menyatakan bahwa lingkungan kerja berpengaruh positif dan signifikan terhadap kinerja karyawan.

Secara teoretis penelitian ini dapat memberikan tambahan pengetahuan dan wawasan yang lebih luas mengenai efektivitas penerapan SIPKD, gaya kepemimpinan, dan lingkungan kerja pada kinerja karyawan Dinas Pariwisata Provinsi Bali, serta penelitian ini dapat berkontribusi terhadap pengembangan teori Technology-to-Performance Chain (TPC) karena teori ini menjelaskan bahwa pengaruh teknologi informasi terhadap kinerja individual.

Penelitian ini diharapkan akan memberikan kontribusi positif bagi pihakpihak yang membutuhkan seperti Dinas Pariwisata Provinsi Bali dimana diharpkan nantinya dapat memberi evaluasi mengenai penerapan SIPKD mempengaruhi kinerja karyawan. Selain hal tersebut, penelitian ini diharapkan dapat menjadi bahan pertimbangan dan referensi bagi penelitian berikutnya yang tertarik untuk meneliti kajian yang sama di masa mendatang.

\section{SIMPULAN}

Efektivitas penerapan SIPKD tidak berpengaruh signifikan pada kinerja karyawan Dinas Pariwisata Provinsi Bali. Hal ini dibuktikan dengan hasil uji statistik yang menunjukan nilai signifikan 0,108 >0,05. Kondisi tersebut menyebabkan karyawan tidak dapat menikmati keuntungan dari penerapan SIPKD. Hal ini bisa saja disebabkan oleh penerapan SIPKD yang baru saja dimulai pada tahun 2018, sehingga pengguna masih perlu melakukan adaptasi agar nantinya penerapan SIPKD bisa berjalan secara efektif dan optimal pada kinerja karyawan Dinas Pariwisata Provinsi Bali.

Gaya Kepemimpinan berpengaruh positif dan signifikan pada kinerja karyawan Dinas Pariwisata Provinsi Bali. Hal ini dibuktikan dengan hasil uji statistik yang menunjukan nilai signifikan 0,007 <0,05. Hal ini berarti bahwa semakin baik seorang pemimpin menerapkan gaya kepemimpinan, maka semakin tinggi kinerja karyawan.

Lingkungan kerja berpengaruh positif dan signifikan pada kinerja karyawan Dinas Pariwisata Provinsi Bali. Hal ini dibuktikan dengan hasil uji statistik yang menunjukan nilai signifikan 0,021 $<0,05$.

Kepala Dinas Pariwisata Provinsi Bali diharapkan mampu memberikan pelatihan,workshop atau diklat bagi pengguna SIPKD sehingga diharapkan pengguna sistem mau meningkatkan teknik personal yang dimiliki dan dapat mempermudah pengguna sistem itu sendiri dalam mengaplikasikan sistem yang ada.

Kepala Dinas Pariwisata Provinsi Bali sebaiknya lebih banyak mendorong pegawai untuk lebih banyak terlibat agar lebih meningkatkan kinerja sistem informasi pengelolaan keuangan daerah, khususnya pada aspek yang perlu ditingkatkan dalam keterlibatan pemakai yaitu keikut sertaan pegawai dalam 
perencanaan sistem informasi pengelolaan keuangan daerah yang dioperasikan di Dinas Pariwisata Provinsi Bali.

Diharapkan untuk menambahkan variable bebas yang lebih mempengaruhi kinerja karyawan kepada para peneliti yang tertarik meneliti kajian yang sama di masa mendatang.

\section{REFERENSI}

Awosejo, O. J. et al. (2013) 'The Effect of Accounting Information Systems in Accounting', International Journal of Advanced Computer Research, 3(3), pp. $2249-7277$.

Bodnar, G. H. and Hopwood (2000) Sistem Informasi Akuntansi. Jakarta: Salemba Empat.

Dubrin, A. J. (2005) Leadership (Terjemahan). 2nd edn. Jakarta: Prenada Media.

Goldfinch, S. (2007) 'Pessimism, computer failure, and information systems development in the public sector', Public Administration Review, 67(5), pp. 917-929. doi: 10.1111/j.1540-6210.2007.00778.x.

Goodhue, D. L. and Thompson, R. L. (1995) 'Task-technology fit and individual performance', MIS Quarterly: Management Information Systems, 19(2), pp. 213-233. doi: 10.2307/249689.

James, L. (1996) Organisasi: Perilaku, Struktur, Proses. Jakarta: Binarupa Aksara.

Kusmayadi, A. W. (2014) Pengaruh Karakteristik Individu, Lingkungan Kerja dan Motivasi terhadap Kinerja Karyawan (Sensus Pada PT. Indomarco Prismatama Wilayah Kota Cirebon). Tesis. Magister Manajemen Universitas Siliwangi: Tasikmalaya.

Negeri, D. J. B. K. D. K. D. (2018) Strategi Implementasi Aplikasi Sistem Pengelolaan Keuangan Daerah (SIPKD). Available at: http://keuda.kemendagri.go.id/sipkd (Accessed: 28 September 2018).

Nitisemito, A. S. (1996) Manajemen Sumber Daya Manusia. Yogyakarta: Gajahmada University Press.

Prista, E. S. (2016) Pengaruh Gaya Kepemimpinan, Motivasi dan Disiplin Kerja Terhadap Kinerja Karyawan CV. Prista Jaya Jember. Skripsi. Sarjana Jurusan Manajemen Fakultas Ekonomi Universitas Jember.

Putra, I. K. A. M. and Putra, I. M. P. D. (2016) ‘Pengaruh Efektivitas Penggunaan, Kepercayaan, Keahlian Pengguna, Dan Kualitas Sistem Informasi Akuntansi Terhadap Kinerja Karyawan', E-Jurnal Akuntansi Universitas Udayana, 17(2), pp. 1516-1545.

Saydam, G. (2000) Manajemen Sumber Daya Manusia. Jakarta: Djambatan.

Schultz, D. P. and Schultz, S. E. (2009) Theories of Personality. 9th edn. United States of America. doi: 10.1093/oxfordjournals.jbchem.a126528.

Sedarmayanti (2009) Tata Kerja dan Produktivitas Kerja. Bandung: CV Mandar Maju.

Siagian, S. P. (2003) Kiat Meningkatkan Produktivitas Kerja. Jakarta: Rineka Cipta.

Siti Nurlaela, Eny Parjanti, K. H. T. dan (2014) 'Pengaruh Sistem Informasi Akuntansi, Gaya Kepemimpinan Dan Kompleksitas Tugas Terhadap Kinerja Karyawan', Jurnal Paradigma Universitas Islam Batik Surakarta, 12(1), pp. 57-70. 
Soudani, S. N. (2012) 'The Usefulness of an Accounting Information System for Effective Organizational Performance', International Journal of Economics and Finance, 4(5), pp. 136-145. doi: 10.5539/ijef.v4n5p136.

Winardi (2007) Manajemen Kinerja. Jakarta: PT. Raja Grafindo Parsada.

Yulianingtyas, R. W. (2008) Pengaruh Kepuasan Karyawan pada Gaya Kepemimpinan dan Lingkungan Kerja terhadap Kinerja Karyawan PT Yogyateks. Skripsi. Sarjana Akuntansi Fakultas Ekonomi Universitas Negeri Yogyakarta.

Yustikarana, P. B. R. and Wirakusuma, M. G. (2019) 'Pengaruh Kemampuan dan Keterlibatan Pengguna Terhadap Kinerja Sistem Informasi Pengelolaan Keuangan Daerah', E-Jurnal Akuntansi Universitas Udayana, 27(3), pp. 1983-2009. 